\title{
The dark side of civil society? How Thailand's civic networks foster
}

\section{autocracy}

Edition 6, 2021

Dr Janjira Sombatpoonsiri

DOI: 10.37839/MAR2652-550X6.3

In the aftermath of Thailand's 2020 pro-democracy protests, around 47 activists and participants [i] -as young as 16 years old-have been charged with Article 112 or lèse majesté that punishes offenders of the monarchy with 15-year jail sentences. Out of this number, at least 17 lawsuits were filed by civic groups such as the Thai Bhakdi and 'We Support [Prime Minister] Prayuth.' A leader of the latter encouraged what they termed 'good citizens' to monitor and report alleged insults of the monarchy, insisting that Article 112 is necessary for defence of the crown.

Vigilante civic activism in Thailand has a long tradition, originating in the 1970s with rightwing militias such as Nawapol and Krathing Daeng. In recent years, royalist civic groups have been re-activated to counter anti-establishment forces deemed a threat to the monarchy. By coalescing with royalist elites, royalist civil society networks operate as repressive forces which reduce the democratic space of deliberation. Civil society's weaponisation of draconian laws helps the regime stifle dissent and plunge Thailand deeper in autocracy.

\section{Features of Thailand's authoritarian civil society}

Considering civil society as a foe of democracy can be counterintuitive. A vibrant 
civil society is typically identified as a crucial trait of democratic society and a driver for democratisation. Accordingly, when political regimes restrict and suppress the rights of civil society, they display anti-democratic traits. The phenomenon of shrinking civic space is a worrying trend also seen in increasingly autocratised regimes such as in Russia, Cambodia, Turkey, Hungary, and India-all of which have devised a host of legal and bureaucratic tools to suppress oppositional civil society. However, certain types of civil society groups can play a role in legitimating nondemocratic regimes and in eroding the democratic space that allows civil society to thrive.

In Thailand, the proliferation of what I define as authoritarian civil society (hereafter ACS) is due to structural conditions, including the entrenchment of establishment elites-the monarchy, the military and their allies in the bureaucracy and businesses, who reject the legitimacy of democracy. Elites' hegemony runs deep at the level of popular consciousness-elites have generally shaped public opinion in ways that make Thais wary of democracy and what are described as its corrupt politicians. For the army, this rhetoric has been used time and again to justify multiple coups to topple civilian governments claimed to be corrupt and/or disloyal. In the 1970s, royalist civic groups were mobilised to aid the authorities' crackdown on leftist students, and the role of these groups is becoming more multifaceted.

The 1990s democracy movement empowered new political forces, including the Thai Rak Thai (TRT) party and its constituents in impoverished regions to seriously contest the dominance of royalist elites. Alarmed by this threat, the royalist elites moved to depose the TRT-led or affiliated governments through two military putsches in 2006 and 2014.

The establishment does not, however, rely only on sticks -it uses political allies to help neutralise threats from the opposition. This has been demonstrated since the March 2019 elections in which the military government which took power 2014 mutated into the current hybrid regime characterised by manipulated elections and aggrandised executive power through constitutional drafting; as well as influence 
over supposedly independent institutions such as the Constitutional Court and the Election Commission. Contemporary ACS groups have proliferated in this context, bolstering the regime through the bottom-up repression of anti-establishment supporters.

Functions of the ACS may overlap with and complement state agencies charged with quelling dissidents-making a mockery of the liberal notion of autonomous civil society. The Thai regime's repression has been implemented through what is known as the Strategic Lawsuit against Public Participation (SLAPP), practices which stifle critics through multiple legal charges, together with digital surveillance. Among others, Article 112 of the Criminal Code (which outlaws lèse-majesté), the computer crime law (which allows the authorities to block content deemed distortive and charge Internet users alleged to spread such content), Article 116 of Criminal Code (which outlaws sedition), and the abuse of defamation law (which punishes those alleged to impair the reputation of other individuals) underpin the effectiveness of the SLAPP. As we shall see, these laws provide ground for ACS groups' participation in the regime's harassment of anti-establishment activists. With regard to digital surveillance, security forces have initiated programmes such as 'Cyber Scouts' and the 'Information Operation' to monitor dissent while generating pro-regime messages on social media platforms. While these units are strictly state actors, citizens can take part. For instance, more than 120,000 students were recruited as Cyber Scouts as of 2017, while high school students in the Reserve Officer Training Corps are reportedly compelled to engage in the Information Operation. In the case of the royally-sanctioned Volunteer 904, individuals are persuaded to become volunteers, with some joining social media campaigns to reinforce royalism in the face of the 2020 pro-democracy protests.

However, royalist elites are not always directing the ACS; some are organic and their activism reflects the ideological polarisation Thailand has undergone. Grassroots-driven division between pro- and anti-establishment supporters has been shown in tit-for-tat street protests opposing governments representing their respective antagonists in 2008, 2009-2010, and 2013-2014. While anti- 
establishment supporters question the existing social hierarchy nurtured by royal feudalism and espouse liberal democratic values, pro-establishment supporters seek to perpetuate Thailand's traditional order that places the king at the top. For them, Western notions of equality and rights are inherently incompatible with the Thai culture. The ACS possesses a sense of agency, determined to preserve the political order of their preference.

\section{Authoritarian civil society's activism: legal attacks and digital vigilantism}

The undermining of Thailand's democracy includes organised ACS protests that set the stage for military interventions, online surveillance, and social media content manipulation. This section focuses on the last two types of activism as they are features of the current hybrid regime.

Between 2010 and 2014, vigilante groups emerged amid anti- and pro-establishment protests to reinforce royalist-nationalist discourses and monitor online opinions hostile to traditional elites. While security apparatus is allegedly connected with some groups, many others are autonomous from the state structure and operate organically. Their tactics linking cyber bullying with physical intimidation aggravate the climate of fear. Major groups with a track record of harassing dissidents are detailed as follows:

- Social Sanction (SS) is one of the early online bullying groups, active between 2010 and 2013, that monitored lèse majesté content on social media. Personal profiles of alleged Article 112 transgressors were shared on the SS Facebook page, where they were subject to defamatory comments such as that they were un-Thai, ungrateful and evil. A co-founder of SS believed that Thailand 'was sinking into an abyss as the result of corrupt politicians and they had no faith in police or any established social institution except the monarchy.' For her, exposing disloyal 'wrongdoers' is one way to 
help making Thailand a better place. At its peak, the SS Facebook page got more than 30,000 likes. About 50 people were bullied, and at least four cases of Article 112-related lawsuits were based on the information shared on the SS page.

- Rubbish Collection Organisation (RCO), founded during the 2013-14 People's Democratic Reform Committee demonstrations, is headed by a former major general, medical doctor, and ultraroyalist, Rienthong Nanna. The RCO combines the established forms of mobbing activism with a professional military organisation structure. It aims to rid Thailand of 'social rubbish,' and to 'eradicate lèse majesté offenders completely' within two years. Its modus operandi consists of compiling a list of Article 112 alleged infringements and notifying the police. If no legal action is taken, the group at times discloses an offender's private address and encourages mobs to harass them at home. In April 2014, the parents of an exiled offender were pressured into filing a case of lèse majesté against their own daughter. In October 2016, the RCO accused several Thais living in Sweden and Belgium of posting YouTube videos violating the Article 112. Subsequently, a handful of Thai residents in Sweden reportedly pestered the accused at her house. While RCO activism has not gained substantive media attention lately, Rienthong continues mobilising royalist supporters against the rising and vocal Future Forward Party alleged of harbouring unpatriotic and republican sentiments. Meanwhile, he has threatened to file a defamation charge against YouTube and Facebook in Thailand if they don't remove antimonarchy content. In response to Human Rights Watch's (HRW) criticisms of the junta, the group denounced HRW's Thai senior researcher as a 'fake' human rights activist because he failed to protect the human rights of the Thai monarchy.

- Other civic efforts to monitor online breaches of Article 112 include the Network of Volunteer Citizens to Protect the Monarchy on Facebook and the Anti-Ignorance Association. These two groups monitor and report of Article 112 cases to the police, some of which have led to charges against anti- 
establishment sympathisers, including a political theatre group. Since the 2014 coup, the number of royalist Facebook pages has multiplied. They share doctored images, which sometimes contain obscene and sexist captions that demonise dissidents. They also misquote activists' interviews or speeches in order to over-state their political partisanship with 'red shirts' (anti-establishment supporters) and disloyalty towards the Palace. In some cases, groups stage protests to call for the arrest of those offending the monarchy.

Organised groups aside, individuals have reported alleged Article 112 violations. According to an iLaw database, out of 108 charges related to Article 112, at least a dozen were filed by ordinary citizens, including a taxi passenger displeased with the driver's comments about the monarchy, and a security guard disturbed by antimonarchy graffito in a shopping mall. In a recent incident, the head of the National Association of Visually Disabled People reported a Facebook comment posted by a blind woman. She later faced a one-year-and-a-half jail sentence. Citizens' reports of Article 112 breaches skyrocketed after King Bhumibol's death in 2016. Mourners, moreover, took matters in their own hands by physically and verbally attacking those they believed had behaved inappropriately in times of grief.

Since the March 2019 election the ruling army's new constitution has created an electorally-uneven playing field, with pro-regime institutions including the Constitutional Court and Election Commission (EC) exploiting legal mechanisms to undercut opposition parties. Civic groups such as Rak Siam Federation (RSF) and Constitutional Protection Organisation (CPO) have provided a 'civic camouflage' for the latter by submitting complaints about the opposition parties' alleged misconduct and thus appearing as if these were truly civic concerns. A case in point was the Constitutional Court's recent disbanding of the Future Forward Party. A CPO representative complained to the Election Commission that the FFP violated an electoral regulation. Subsequently the Constitutional Court disqualified the FFP's leader from parliament and dissolved the party in February 2020. Similarly, the Rak Siam Federation filed a complaint to the Election Commission, claiming all seven 
opposition parties violated a constitutional provision by participating in a highly politically charged public forum and should therefore be dissolved. Although the Election Commission refused to take up the complaint by the RSF, the militaryassociated Internal Security Operations Command lodged a sedition charge against 12 opposition party leaders, academics and activists.

These vigilante groups are in synergy with rightwing media including the Thailanguage T-News and Chaopraya News, and the English-language The New Atlas, Alt Thai News Network (ATNN), and New Eastern Outlook (NEO)[ii], which often frame anti-establishment voices as traitors-implicitly calling for a government crackdown on them. These media companies insist that foreign support for Thailand's opposition movements is a US-CIA scheme for regime change in order to revive Western hegemony in South East Asia.

Mainstream media sometimes helps propagate this narrative. For instance, in August 2016, The Nation, a mainstream, English-language newspaper, published the so-called 'Soros Leaks', claiming that the Fund for Open Society and the National Endowment for Democracy had sponsored a number of dissidents in Thailand. In early 2018 this alleged scandal resurged on the prominent Thansetthakit news website, reaffirming the narrative of Western intervention in Thailand's domestic affairs. Many social media influencers with tens of thousands of followers reposted it and expressed their agreement with the story. In the comments section linked to the news article, Thai organisations receiving international support have been disparaged as 'parasites' and 'traitors'. Some comments are extremely hostile, wishing the 'wipe out' of the 'families of these traitors.' In 2017, a columnist for Thairath, a national tabloid, proposed that the junta should enact a law that circumvents the international funding of NGOs, as happened in India, Russia, and Hungary. 


\section{Authoritarian civil society and the 2020 anti-establishment protests}

As anti-establishment demonstrations rocked Thailand between June and December 2020, the ACS resurged, staging counter-protests while helping the authorities monitor royal offences. The youth-led anti-establishment movements did not shy away from Thailand's most taboo subject: the monarchy. In August 2020, they demanded reform of the monarchy in line with the constitutional monarchy. Protest speeches targeted royal family members, particularly the concentration of wealth and power.

In response, an array of ACS groups rallied mass support to protect the Crown. Founded in 2019 in parallel with the Future Forward Party's emergence, the Thai Move Institute and its associated online media outlets such as the METTAD and the Truth framed protesters as anti-monarchy, conspiring with George Soros and western NGOs to destroy Thailand. This claim inspired the right-wing group Thai Bhakdi led by Warong Dechgitvigrom, a former member of parliament-turned staunch royalist, who staged counter-protests from August to December 2020. At times, these protests escalated into head-on confrontations with anti-establishment demonstrators, at which police were accused of doing little to prevent such clashes in at least in one event. Anti-establishment supporters claimed that royalists deliberately provoked clashes so images of street chaos would increase support for a military coup.

When the royalist provocation seemed counterproductive, Warong, in December 2020, urged his followers file a lawsuit against offenders of the monarchy. Ever since, 'volunteers' have collected online evidence that potentially implicates antiestablishment activists in lèse majesté activity. Such a tactic is particularly dangerous in the Thai legal context in which the police, upon the receipt of complaints regarding lèse majesté, are under pressure to charge the accused, or risk themselves being accused of violating laws relating to their duties. For this reason, 
Article 112 charges have skyrocketed since the end of 2020, resulting in the denial of bail and imprisonment of some leading activists. A 'chilling effect' is generated among anti-establishment supporters.

In a divided country like Thailand, it is common that citizens harbouring opposing views, be they progressive or conservative, express their discord and legitimately exercise their freedom of expression. However, the ACS employ anti-democratic practices that exploit draconian laws to silence their opponents, while aiding authorities in eliminating their opponents. In so doing, the ACS contributes to the expansion of autocratic space at the expense of democratic pluralism.

\section{Footnotes}

\section{[i] A human rights activist asserts that the number of Article 112 charges is as high as 63 cases as of March 3, 2021 (private conversation, 3 March 2021).}

[ii] It should be noted that Facebook has recently taken down the page of New Eastern Outlook due to allegations of spreading disinformation. New Eastern Outlook is also accused of linkage with the Russian government.

Related webinar: Human rights and democratic regression in Asia.

Image: Protesters use a three finger salute to protest against the government, demand for new constitution and monarchy reform. Bangkok, August 16, 2020. Credit: Adirach Toumlamoon/Shutterstock. 